The Reverse Notation:

Introducing Negative Digits with Twelve as Base. By J. Halcro-Johnston. Pp. $\mathrm{x}+74$. (Glasgow and London : Blackie and Son, Ltd., 1938.) 3s. 6d. net.

$\mathrm{N}$ this interesting book, the author explains a new notation which he has devised to remove the main defeots of the Arabic notation. The two main characteristics of the system, called the reverse notation, are the introduction of negative digits and the adoption of 12 as the radix or base. The consecutive sequence of digits is written : $\overline{6}, \overline{5}, \overline{4}, \overline{3}, \overline{2}, \overline{\mathbf{1}}$, $0,1,2,3,4,5,6$, so that any number like 8 is denoted by $1 \overline{4}$, whilst $1 \overline{5} 4$ represents seven dozen and four. The notation is applied to the ordinary rules of arithmetic and the author claims that the numbers of the reverse notation "are balanced about their centres of gravity", which is not the case with the Arabic system.

The whole scheme is undoubtedly very ingenious, but when judged impartially, there appear to be far more difficulties in the notation than there are disadvantages in the existing Arabic system. The initial trouble that teachers have in introducing and working with negative characteristics in logarithms is well known. Indeed, to arouse a true concept of a negative number is by no means an easy problem either in psychology or pedagogy. Yet in the system before us, negative digits abound; for example, log $3=0.54 \overline{4} 0, \quad \log 6 \cdot \overline{3} \overline{5} 5=\overline{\mathrm{l}} \cdot 320 \overline{4}, \pi=3 \cdot \overline{\mathbf{4}} \overline{54}$ and on page 47 , the number of days in the year is represented as $265 \cdot 3 \overline{1} \overline{1} 63$ !

The author fully realizes that the introduction of such a notation is far from being a practical proposition, but hopes that it will be judged by the principle of the survival of the fittest. It is, nevertheless, very difficult to see how the system can first be introduced. Are accountants, scientific and technical computors, business men, etc., expected to incur the expense of changing the basic notation upon which they have made their calculations for so long ? If they were sufficiently convinced of the advantages of the system to try the experiment, would this ultimately lead to the introduction of the notation into schools, where it should logically begin to evolve? One wonders, however, in this eventuality, what the teachers of arithmetic, especially in primary schools, would say to such a suggestion.

F. G. W. B.

The Macaulay Institute for Soil Research

Collected Papers, Vol. 1. Edited by Dr. W. G. Ogg. Pp. $16+54$ papers. (Aberdeen : Macaulay Institute for Soil Research, 1938.) $21 s$.

$\mathrm{T}$ HE Macaulay Institute for Soil Research was founded for the purpose of studying possibilities of land reclamation on the Island of Lewis, and of raising the standard of agriculture and living of its inhabitants. Sir Robert Greig states in the preface that, since the foundation of the Institute, which is in Aberdeen, and of its experimental farm near Stornoway, Lewis has become more than selfsupporting in milk and eggs, and fine pastures have appeared and are extending over the formerly worthless peat bogs. The Institute has justified its existence, and has tended inevitably to extend its research activities beyond its original field of peat. land reclamation.

These fifty-four reprints of papers by members of the staff indicate the steady growth in the scope of the Institute's work. The Macaulay Institute is the only British station devoted entirely to soil research. From peat studies it has branched out into the chemistry and physics of mineral soils, and latterly into soil classification and survey. One can trace in these papers the gradual evolution of a still incompletely formed "Macaulay" school of thought in soil science in which modern Russian and ancient Scottish beliefs are struggling for mastery. The papers themselves naturally vary in quality; some have obviously been included in order to make the collection complete rather than for their intrinsic value; but, omitting these, a high standard is maintained. It is noteworthy that most of the recently published papers deal with soil chemistry, classification and survey, rather than peat-land reclamation. This indicates a welcome development. Should Britain ever decide to take stock of its land, the Macaulay Institute would have an important part to play in the stocktaking. This collection of papers shows that it is already equipped for the part and can play it without detriment to the original purpose for which the Institute was founded.

\section{Pyrenean Festivals :}

Calendar Customs, Music and Magic, Drama and Dance. By Violet Alford. Pp. $x+286+16$ plates. (London: Chatto and Windus, 1937.) 15s. net.

NISS ALFORD is well known as a student of VI the folk-dance and song of European peasantry, but the Pyrenees is a region which in this subject she has made peculiarly her own province. In this volume, resthetically delightful, as well as scientifically valuable, she has reviewed the results of some years of observation on both sides of the political frontier among the inhabitants of the Pyrenean regions from Catalonia on the east to the Basque country in the west. Nor has she confined her studies to dance and song, for she deals here with some remarkable forms of custom and magical belief which serve to throw light on the main theme.

The ethnological character of the peoples, as well as the geographical conditions of their habitat, have made for an intense conservatism in the past, which undoubtedly has led to the preservation in the dances of religious and cultural concepts, which in their origin are probably older than anything found elsewhere at present in Europe. Such, for example, is the remarkable cult of the bear; while an apparent transformation into animal form represented in the dance recalls the fact that it is in this country that there occurs the palæolithic painting of the animal. magician in the cave of Trois Frères of Ariege.

Miss Alford's work is a veritable gold mine for evidence of survivals of primitive modes of thought, and as such needs no further commendation to students of folk-lore and primitive religion. 